\title{
Characterization of COVID-19 Patients in an Intensive Care Unit
}

\author{
Alberto Dariel Ramirez Gonzalez", Mabel Montero Castrillon, Lazaro Vazquez Vazquez \\ Clinical Science Department, Salvador Allende Faculty, Medical Science University of the Havana, Havana, Cuba \\ Email address: \\ alberto.ramirez90@nauta.cu (A. D. R. González), mabelmonterocastrillon89@gmail.com (M. M. Castrillón), \\ lazaro.vazquez@infomed.sld.cu (L. V.Vázquez) \\ ${ }^{*}$ Corresponding author
}

\section{To cite this article:}

Alberto Dariel Ramirez Gonzalez, Mabel Montero Castrillon, Lazaro Vazquez Vazquez. Characterization of COVID-19 Patients in an Intensive Care Unit. International Journal of Clinical and Experimental Medical Sciences. Vol. 7, No. 5, 2021, pp. 143-151. doi: $10.11648 / j$.jijcems.20210705.13

Received: September 21, 2021; Accepted: October 8, 2021; Published: October 15, 2021

\begin{abstract}
At the end of 2019 a new coronavirus caused an epidemic of acute respiratory disease in Wuhan, China. The World Health Organization called this condition "coronavirus disease 2019" and declared it pandemic on 11 March 2020. On that same date the first three COVID-19 cases were diagnosed in Cuba. The Acute Physiology and Chronic Health Evaluation II (APACHE II) is the disease severity scoring system most commonly used in ICUs. An observational descriptive prospective cohort study was carried out with the objective of describing the behavior of 20 SARS-CoV-2 positive cases in an intensive care unit. This was realized from March to July 2020 at the Intensive Care Unit of Dr Salvador Allende Clinical Surgical Hospital in Havana, Cuba. The study population was all the patients admitted for positive SARS-CoV-2 ( $\mathrm{n}=20)$. Mean age was $64.35 \pm 15.21$ years. Male sex prevailed. Mean hospital stay was 10.05 \pm 5.5 days. Mean APACHE II was 16.6 \pm 8.9 . The prevailing symptoms were fever (55\%), coughing (25\%) and dyspnea (20\%). Mortality of COVID-19 patients was associated to age, a longer stay in the intensive care unit, high APACHE II scores, reduced erythrosedimentation values and lymphocyte count. Hypertension was the most common pathological antecedent.
\end{abstract}

Keywords: Intensive Care Unit, Severe Acute Respiratory Syndrome, Apache, Mechanical Ventilation, COVID-19

\section{Introduction}

At the end of 2019, a new coronavirus, called SARS-CoV-2 (severe acute respiratory syndrome coronavirus 2 ), it caused an epidemic of acute respiratory disease in Wuhan, China. [1]

The World Health Organization named this disease coronavirus disease 2019 (COVID-19) [2] and on March 11, 2020 it was declared a pandemic. [3] On the same day, the first three cases of COVID-19 were confirmed in Cuba. [4]

As of July 13, 185 countries report COVID-19 cases, with figures amounting to $12,875,963$ confirmed cases and 568,628 deaths, for a fatality of $4.41 \%$. The region of the Americas reached $52.72 \%$ of world reports to that date, with 288,759 deaths, for a fatality of $4.25 \%$. At the end of July 13 , in Cuba, 2,432 positive samples were reported, a cumulative 87 deaths, 2 evacuated, and 2,258 recovered patients. [5]

The clinical presentation of COVID-19 is variable, from mild to severe forms. It has been reported that $25.9 \%$ of patients require admission to intensive care units (ICU), and $20.1 \%$ develop adult respiratory distress syndrome (ARDS). [6]

Prediction of survival is vital, as it allows defining criteria for admission to ICUs, rationalizing medical care according to the degree of need, and distributing health resources efficiently. [7, 8]

The Acute Physiology and Chronic Health Evaluation II (APACHE II) is the disease severity scoring system most commonly used in ICUs (Table 5). [9] In recent years, interest in the CONUT index (nutritional control, acronym in Spanish) has increased, [10] scoring system of three biochemical indicators, easy to acquire and apply (Table 6). [11]

The authors set themselves the objective of describing the behavior of 20 positive cases to SARS CoV-2 in the ICU of the Salvador Allende General Hospital, given the importance 
of this pandemic, the need to increase scientific knowledge in relation to this issue.

\section{Method}

Observational, descriptive, cohort and prospective study, applied between March and July 2020, in the ICU of the Salvador Allende Surgical Clinical Hospital from Havana, Cuba. The population consisted of all admitted patients, positive for SARS CoV-2 $(n=20)$.

\subsection{Inclusion Criteria}

All cases confirmed to SARS CoV-2 by Reverse Transcription and Real Time Polymerase Chain Reaction (RT-PCR).

\subsection{Exclusion Criteria}

Cases discarded to SARS-CoV-2 by RT-PCR.

Insufficient data collected to complete the necessary variables in this investigation.

Variables analyzed: age, sex, ICU stay, discharge status, comorbidities, complementary, epidemiological link, invasive mechanical ventilation (IMV), complications, predominant symptoms, pharmacological therapy, APACHE II score and CONUT.

The Microsoft Office Professional Plus 2016 version 16.0 program for Windows was used in the preparation of the final text and the database. The results were expressed in relative and absolute frequencies, percentages and measures of dispersion. A 95\% confidence interval (CI) was applied, the $p$ value was found, and in some cases the odds ratio (OR) and the relative risk $(R R)$.

\section{Ethical Aspects}

The research was carried out in accordance with the principles of the Declaration of Helsinki at the $64^{\text {th }}$ General Assembly, Fortaleza, Brazil, October 2013.

\section{Results}

In this series, the male sex predominated (55\%). The 45-64 age group stood out by $45 \%$. Values from 29 to 101 years and an average of $64.35 \pm 15.21$ years (CI 57.7-71) were recorded (Table 1).

The stay averaged $10.05 \pm 5.5$ days (CI 8.9 - 12.1) (Table 1).

The average APACHE II score was $16.6 \pm 8.9$ (CI 12.7-20.5) and an adjusted probability of death index that ranged from $7.6 \%$ to $81 \%$.

The most frequent symptoms were: fever (55\%), cough (25\%) and dyspnea (20\%). Men reported fever more (ratio 6: 5) (Table 1). Other manifestations were: anosmia or hyposmia, dysgeusia, asthenia, anorexia, sore throat and headache.

Regarding the epidemiological link, ten patients (50\%) had contact with positive cases, and in the other half, the source of infection was unknown at the time of admission (Table 1).

From the date of onset of symptoms to admission to the ICU, the mean time was 7.61 \pm 2.51 days (CI 6.5 - 8.7). (Table 1).

$35 \%$ of the cases presented moderate malnutrition and $30 \%$ mild. Mild malnutrition predominated in women, and moderate in men (Table 1).

Table 1. Characterization of the population according to sex.

\begin{tabular}{|c|c|c|c|c|c|}
\hline \multirow{2}{*}{ Analyzed variables } & \multicolumn{2}{|l|}{ Sex } & \multirow{2}{*}{$\begin{array}{l}\text { Total No. } \\
(\%)\end{array}$} & \multirow{2}{*}{$P$ value } & \multirow{2}{*}{ CI } \\
\hline & Female No. (\%) & Male No. (\%) & & & \\
\hline \multicolumn{6}{|l|}{ Ages ranges } \\
\hline$<45$ & $1(5)$ & $0(0)$ & $1(5)$ & \multirow{4}{*}{0,695} & \multirow{9}{*}{$8,8-12,1$} \\
\hline $45-64$ & $3(15)$ & $6(30)$ & $9(45)$ & & \\
\hline $65-74$ & $3(15)$ & $2(10)$ & $5(25)$ & & \\
\hline$\geq 75$ & $2(10)$ & $3(15)$ & $5(25)$ & & \\
\hline Average stay in ICU (Days \pm SD) & $10,11 \pm 4,9$ & $10,18 \pm 5,3$ & $10,05 \pm 5,5$ & \multirow{5}{*}{0,3088} & \\
\hline $7-14$ & $5(25)$ & $6(30)$ & $11(55)$ & & \\
\hline $15-22$ & $0(0)$ & $3(15)$ & $3(15)$ & & \\
\hline $23-30$ & $2(10)$ & $1(5)$ & $3(15)$ & & \\
\hline$>30$ & $2(10)$ & $1(5)$ & $3(15)$ & & \\
\hline \multicolumn{5}{|l|}{ Main symptom (Reason for consultation) } & \\
\hline Fever & $5(25)$ & $6(30)$ & $11(55)$ & \multirow{2}{*}{0,9551} & \\
\hline Cough & $2(10)$ & $3(15)$ & $5(25)$ & & \\
\hline \multicolumn{5}{|l|}{ Epidemiological link } & \multirow{11}{*}{$6,5-8,7$} \\
\hline Contact with positive case & $7(35)$ & $3(15)$ & $10(50)$ & \multirow[t]{2}{*}{0,0722} & \\
\hline No antecedents & $2(10)$ & $8(40)$ & $10(50)$ & & \\
\hline Time from date of onset of symptoms to ICU admission (Days \pm SD) & $3 \pm 2,6$ & $4,5 \pm 2,0$ & & \multirow{6}{*}{0,7415} & \\
\hline \multicolumn{4}{|l|}{ CONUT } & & \\
\hline Normal & $1(5)$ & $2(10)$ & $3(15)$ & & \\
\hline Mild & $5(25)$ & $2(10)$ & $7(35)$ & & \\
\hline Moderate & $2(10)$ & $4(20)$ & $6(30)$ & & \\
\hline Severe & $1(15)$ & $3(15)$ & $4(20)$ & & \\
\hline Complications & & & & \multirow{2}{*}{0,7415} & \\
\hline Yes & $4(20)$ & $3(15)$ & $7(35)$ & & \\
\hline
\end{tabular}




\begin{tabular}{|c|c|c|c|c|c|}
\hline \multirow{2}{*}{ Analyzed variables } & \multicolumn{2}{|l|}{ Sex } & \multirow{2}{*}{$\begin{array}{l}\text { Total No. } \\
\text { (\%) }\end{array}$} & \multirow{3}{*}{ P value } & \multirow{3}{*}{ CI } \\
\hline & Female No. (\%) & Male No. (\%) & & & \\
\hline No & $5(25)$ & $8(40)$ & $13(65)$ & & \\
\hline \multicolumn{6}{|l|}{ Mechanical Ventilation } \\
\hline Yes & $4(20)$ & $2(10)$ & $6(30)$ & \multirow[t]{2}{*}{0,4327} & \\
\hline No & $5(25)$ & $9(45)$ & $14(70)$ & & \\
\hline \multicolumn{5}{|l|}{ Status at discharge } & \\
\hline Alive & $6(30)$ & $9(45)$ & $15(75)$ & \multirow[t]{2}{*}{0,7952} & \\
\hline Dead & $3(15)$ & $2(10)$ & $5(25)$ & & \\
\hline \multicolumn{5}{|l|}{ Comorbilities } & \\
\hline$<2$ & $5(25)$ & $6(30)$ & $11(55)$ & \multirow{3}{*}{0,6377} & \\
\hline $2-3$ & $4(20)$ & $4(20)$ & $8(40)$ & & \\
\hline$\geq 4$ & $0(0)$ & $1(5)$ & $1(5)$ & & \\
\hline
\end{tabular}

Abbreviations: CI: Confidence index; SD: Standard deviation; CONUT: Nutritional control (acronym in Spanish)

The 45-64 year-old group was concentrated between the 7-14 points (35\%) of the APACHE II score, while scores $\geq 23$ were located in older age groups (Table 2).

Table 2. Characterization of the population according to age.

\begin{tabular}{|c|c|c|c|c|c|c|}
\hline \multirow{3}{*}{ Analyzed variables } & \multicolumn{4}{|c|}{ Ages ranges No. (\%) } & \multirow{2}{*}{$\begin{array}{l}\text { Total } \\
\text { No. }(\%)\end{array}$} & \multirow{2}{*}{ P value } \\
\hline & $<45$ & $45-64$ & $65-74$ & $\geq 75$ & & \\
\hline & $1(5)$ & $9(45)$ & $5(25)$ & $5(25)$ & $20(100)$ & \\
\hline \multicolumn{7}{|l|}{ Status at discharge } \\
\hline Alive & $1(5)$ & $9(45)$ & $3(15)$ & $2(10)$ & $15(75)$ & 0,0656 \\
\hline Dead & $0(0)$ & $0(0)$ & $2(10)$ & $3(15)$ & $5(25)$ & \\
\hline Average stay in ICU (Days \pm SD) & $3 \pm 0$ & $8,9 \pm 5,7$ & $13,4 \pm 5,4$ & $10,8 \pm 5,3$ & & \\
\hline \multicolumn{7}{|l|}{ APACHE II } \\
\hline $7-14$ & $1(5)$ & $7(35)$ & $2(10)$ & $1(5)$ & $11(55)$ & \multirow{4}{*}{0,2646} \\
\hline $15-22$ & $0(0)$ & $2(10)$ & $0(0)$ & $1(5)$ & $3(15)$ & \\
\hline $23-30$ & $0(0)$ & $0(0)$ & $1(5)$ & $2(10)$ & $3(15)$ & \\
\hline$>30$ & $0(0)$ & $0(0)$ & $2(10)$ & $1(5)$ & $3(15)$ & \\
\hline CONUT & & & & & $3(15)$ & \\
\hline Normal & $0(0)$ & $1(5)$ & $1(5)$ & $1(5)$ & $7(35)$ & \\
\hline Mild & $0(0)$ & $4(20)$ & $1(5)$ & $2(10)$ & $6(30)$ & 0,8430 \\
\hline Moderate & $1(5)$ & $3(15)$ & $1(5)$ & $1(5)$ & $4(20)$ & \\
\hline Severe & $0(0)$ & $1(5)$ & $2(10)$ & $1(5)$ & & \\
\hline \multicolumn{7}{|l|}{ Mechanical Ventilation } \\
\hline Yes & $0(0)$ & $0(0)$ & $3(15)$ & $3(15)$ & $6(30)$ & \multirow[t]{2}{*}{0,0235} \\
\hline No & $1(5)$ & $9(45)$ & $2(10)$ & $2(10)$ & $14(70)$ & \\
\hline \multicolumn{7}{|l|}{ Comorbilities } \\
\hline$<2$ & $0(0)$ & $7(35)$ & $4(20)$ & $0(0)$ & $11(55)$ & \multirow{3}{*}{0,0659} \\
\hline $2-3$ & $1(5)$ & $2(10)$ & $1(5)$ & $4(20)$ & $8(40)$ & \\
\hline$\geq 4$ & $0(0)$ & $0(0)$ & $0(0)$ & $1(5)$ & $1(5)$ & \\
\hline
\end{tabular}

Abbreviations: CI: Confidence index; SD: Standard deviation; CONUT: Nutritional control index (acronym in Spanish)

Seven of the cases $(35 \%)$ presented complications in their evolution: ARDS (20\%), coinfection due to community-acquired bacterial bronchopneumonia (15\%), acute renal failure (15\%), septic shock (15\%), multi-organ dysfunction syndrome (10\%), nosocomial bronchopneumonia $(10 \%)$, acute myocardial infarction $(10 \%)$ and upper gastrointestinal bleeding (5\%). These incidences only occurred in $\geq 65$ years (Table 1 ).

$30 \%$ of the patients required IMV, all were $\geq 65$ years old, with a predominance of females. $83.33 \%$ [5] died, of which four had severe or moderate ARDS (RR 16.7) according to the Berlin classification. [12] The average use of positive end-expiratory pressure (PEEP) was optimal. of $16.5 \pm 2.1 \mathrm{~cm}$ $\mathrm{H}_{2} \mathrm{O}$ (CI 15.6-17.4), and the initial ventilatory modality was volume control ventilation (VCV). One of the cases was placed in the prone position after the first 12 hours of admission to the ICU. It is striking that $5 \mathrm{~cm} \mathrm{H}_{2} \mathrm{O}$ of PEEP was required less compared to the supine position. Prone decubitus was contraindicated in the other cases due to hemodynamic instability.

The case in which successful ventilatory weaning was achieved was achieved in positive bippression (BiPAP) modality, which meant lower requirements for sedation and muscle relaxation, and less IMV time (5 days), despite advanced age.

Non-invasive ventilation was used in none of the patients.

Regarding deaths ( $25 \%$ of $n$ ), the ages ranged between 66 and 101 years, with an average of $78.6 \pm 17.3$ years (CI 71-86.2). When relating this variable to sex, women stood out (ratio 3:2). The stay of the deceased did not vary significantly with respect to the survivors (Table 2).

The deceased presented APACHE II scores $\geq 23$, averaging $28.3 \pm 8.6$ points (CI 24.5-32.1), with an average probability of dying of $62.9 \pm 23.5 \%$ (CI 52.6- 73.2) $(\mathrm{p}<0.05)$. Four of the 
deaths $(80 \%)$ presented some degree of malnutrition. The highest proportion of deaths had between 2-3 comorbidities
$(15 \%$ of $n)$; arterial hypertension was the most common condition (OR: 1.71; RR: 1.5) (Table 3).

Table 3. Characterization of the population according to Status at discharge.

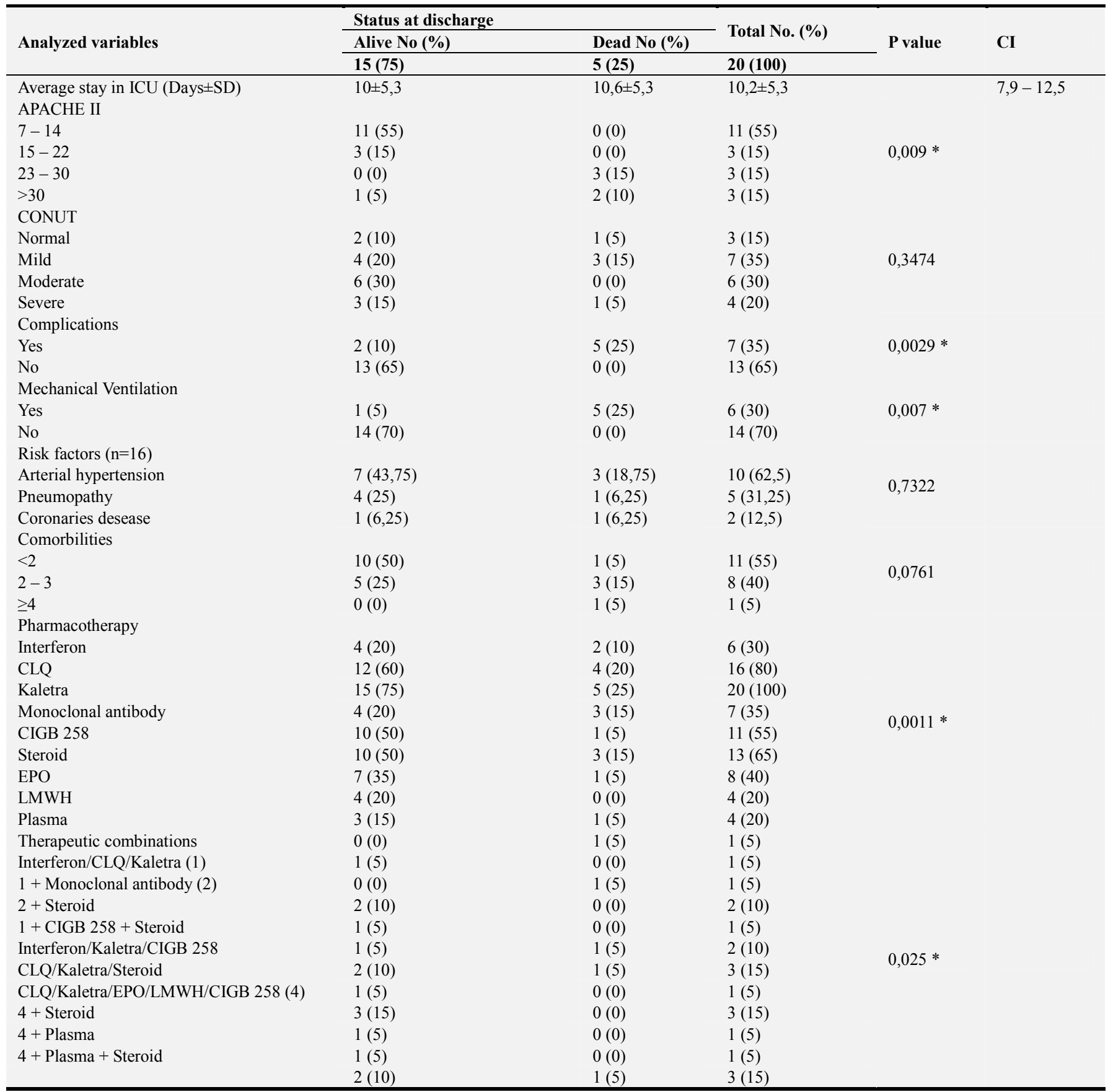

Abbreviations: CLQ: Chloroquine; EPO: Erythropoietin; LMWH: Low Molecular Weight Heparin; CIGB 258: Inmunomodulatory peptide created for Hygiene and Biotechnology Center of Cuba (acronym in Spanish); Plasma: convalescent plasma.

$* \mathrm{p}<0,05$

The most frequent pathological antecedents were: arterial hypertension $(50 \%)$, bronchial asthma $(20 \%)$, ischemic heart disease $(15 \%)$ and chronic obstructive pulmonary disease $(10 \%)$. In less frequency, type II diabetes mellitus, hypothyroidism, chronic adrenal insufficiency, cellular immunodeficiency, morbid obesity, senile dementia, Alzheimer's type dementia, prostatic adenocarcinoma with pulmonary metastases, pulmonary hypertension, valvular heart disease and HIV were recorded.

Regarding comorbidities, the group with less than two comorbidities stood out (55\%), followed by $2-3(40 \%)$; the men were slightly superior to the women in the first group (ratio of 6: 5), and they were even in the group (Table 3).

Pharmacological treatment was individualized according to 
the Cuban protocol established for COVID-19 and the guidelines of the institution's expert committee.

All cases received empirical antibiotic therapy with Ceftriaxone if there was no hypersensitivity or a higher antibiotic scale. $100 \%$ took Kaletra, $80 \%$ chloroquine (CLQ), $65 \%$ steroids and 55\% CIGB 258. The most used therapeutic combinations were CLQ/Kaletra/Monoclonal Antibody/Steroids, CLQ/Kaletra/EPO/LMWH/CIGB 258 and
CLQ/Kaletra/EPO/LMWH/CIGB 258/Plasma/Steroids, all by $15 \%$ (Table 3 ).

Of the survivors, the most used combination was CLQ/Kaletra/EPO/LMWH/CIGB 258 (15\%). Different drug combinations were used in the deceased (Table 3 ). $75 \%$ of the patients presented bilateral interstitial infiltrates on chest $\mathrm{x}$-rays, occurring in $100 \%$ of the deceased (Table 4 ).

Table 4. Comparison between status at discharge and complementary studies.

\begin{tabular}{|c|c|c|c|c|c|}
\hline \multirow{3}{*}{ Complementary studies } & \multicolumn{2}{|c|}{ Status at discharge } & \multirow{3}{*}{ Total No. (\%) } & \multirow{3}{*}{ CI } & \multirow{3}{*}{ P value } \\
\hline & Alive No. (\%) & Dead No. (\%) & & & \\
\hline & $15(75)$ & $5(25)$ & & & \\
\hline Chest X-rays & & & $20(100)$ & & \\
\hline Presence of interstitial infiltrates & $10(50)$ & $5(25)$ & $15(75)$ & & 0,3711 \\
\hline Absence of injuries & $5(25)$ & $0(0)$ & $5(25)$ & & \\
\hline \multicolumn{6}{|l|}{ Transaminases (IU/L) } \\
\hline GPT & $45,8 \pm 32,9$ & $125,4 \pm 36,4$ & $65,7 \pm 48,3$ & $44,5-86,9$ & 0,0000 \\
\hline LDH (IU/L) & $275,9 \pm 263,5$ & $466,8 \pm 248$ & $335,6 \pm 240,3$ & $230,3-440,9$ & 0,0000 \\
\hline $\operatorname{ESR}\left(\mathrm{mm}^{3} / \mathrm{s}\right)$ & $73,1 \pm 37,2$ & $46,4 \pm 39,5$ & $65,66 \pm 36,2$ & $49,8-81,5$ & 0,0146 \\
\hline Lymphocyte count & $1566 \pm 832$ & $1220 \pm 861$ & $1480 \pm 819$ & $1121,1-1838,9$ & 0,0000 \\
\hline Lactate & $1,18 \pm 0,51$ & $1,78 \pm 0,51$ & $1,33 \pm 0,51$ & $1,1-1,6$ & 0,7273 \\
\hline Albumin (g/L) & $30,7 \pm 5,7$ & $35 \pm 6,2$ & $31,8 \pm 5,7$ & $29,3-34,3$ & 0,5958 \\
\hline Cholesterol (mmol/L) & $3,7 \pm 1,1$ & $3,8 \pm 1,2$ & $3,7 \pm 1,1$ & $3,2-1,1$ & 0,9709 \\
\hline
\end{tabular}

Abbreviations: ESR: Erythrocyte sedimentation rate; LDH: Lactate deshydrogenase; GPT: Glutamic pyruvic transaminase; GOT: Glutamic oxaloacetic transaminase

The mean GPT was 65.7 $\pm 48.3 \mathrm{IU} / \mathrm{L}$ (CI 44.5-86.9), almost doubling its value in the deceased $(125.4 \pm 36.4 \mathrm{IU} / \mathrm{L})$. The average GOT was 70.9 $\pm 83.2 \mathrm{IU} / \mathrm{L}$ (CI 34.4-107.4), doubling its value in deaths $(177 \pm 104 \mathrm{IU} / \mathrm{L})$ (Table 4$)$.

LDH increased in a high percentage of cases; for an average of 335.6 \pm 240.3 IU/L (IC 230.3-440.9), higher for the deceased (466.8 $\pm 248 \mathrm{IU} / \mathrm{L})$. Their figures ranged from 229 to 1225 IU/L (Table 4).

ESR averaged $65.66 \pm 36.2 \mathrm{~mm}^{3} / \mathrm{s}$ (CI 49.8-81.5). The decrease in its value in the deceased $\left(46.4 \pm 39.5 \mathrm{~mm}^{3} / \mathrm{s}\right)$, in relation to its increase in the survivors (Table 4), is noteworthy.

The lymphocyte count decreased in the deceased $(1220 \pm 861)$ compared to the survivors and the general average (Table 4).

The average lactate was conserved in survivors and deceased; remember that these tests were obtained $24 \mathrm{~h}$ after admission to the ICU and not progressively (Table 4).

Serum albumin in the deceased was, on average, slightly decreased. Average serum cholesterol was preserved (Table 4).

\section{Discussion}

The average population was aged, which highlights age as a relevant variable that affects therapeutics, evolution and prognosis. Male representation predominated.

Several authors have identified age as the main risk factor for severe disease, adjusting its threshold to 65 years. [16-19] Also in a New York study, the mean was 62.2 years and $60 \%$ were men. [20] Values similar to those found in this research.

The ICU stay averaged 10 days, and age proportionally affected the increase in length of stay. On this, the hospital mean for Fei Zhou and others was 22 days, [20] double the value referred to in this research.

The high APACHE II scores demonstrate the complexity of the cases attended. Age was directly proportional to the APACHE II score.

According to Carboni et al., the average APACHE II score on admission was 9, [21] lower than that reported in our study.

The admitted cases were symptomatic or minimally symptomatic; the latter, with radiological, hemogasometric, humoral and comorbid conditions, which conditioned their admission.

In a New York study, the most common symptoms were: cough (79.4\%), fever (77.1\%) and dyspnea (56.5\%); [20] similar to what was found in this study.

Chinese research reports fever, cough, odynophagia, decay, myalgia, and gastrointestinal symptoms. [18, 22] In others, anosmia and ageusia are also described. [23, 24]

Half of the cases in this study had epidemiological links.

According to Carboni et al in their work, three cases had traveled to affected areas, and another four affected by transmission in conglomerates and one community. [21]

The complications observed occurred in advanced ages. This reaffirms the weight of age in the probability of presenting an unfavorable evolution.

Fei Zhou et al. Found sepsis, respiratory failure, ARDS, heart failure, and septic shock among the most common complications. [17] Similar to this study.

The authors' attention was drawn to the presence of marked hypoxemia $\left(\mathrm{PaO}_{2} / \mathrm{FiO}_{2}<200\right)$ with relatively preserved ventilatory mechanics and the low perception of severity of the patient prior to orotracheal intubation; also being observed 
in a significant number of cases of non-ventilated patients, these, with $\mathrm{PaO}_{2} / \mathrm{FiO}_{2}$ between 200-300, but responding to oxygen therapy at non-usual continuous flows $(10-20 \mathrm{~L} / \mathrm{min})$ by mask or oxygen fork, with return to their oxygenation values gradually around the tenth day from the FIS. Desaturation by pulse oximetry was a late sign of impending severity.

In the study by Carboni et al., A high percentage of cases required IMV, and all ventilated patients presented ARDS. [21] Bhatraju et al., Were also impressed by severe hypoxemia with relatively preserved ventilatory mechanics, in their study. [25] $\mathrm{Wu}$ and others report that patients with moderate disease may have dyspnea, but blood oxygen saturation is usually at least $94 \%$ while the patient is breathing room air. [19]

In a study in The Lancet magazine, 54 of the 191 cases analyzed died. The OR of hospital deaths was higher in patients with diabetes and coronary artery disease. The average stay of the deceased was 10 days. It also confirms that the increase in age was associated with mortality, [17] similar to the results of the present study.

In this series, a list of chronic noncommunicable diseases was reported, which constitute risk factors for the progression of COVID-19. [16] In several studies, hypertension, pre-existing lung disease, and diabetes are risk factors for the development of severe disease. [17, 18] Pre-existing cardiovascular disease, $[17,18,26]$ and obesity are other of these factors. [27]

Regarding drug treatment, all cases received empirical antibiotic therapy and Kaletra. To a lesser degree, CLQ, steroids and CIGB 258, according to the Cuban protocol and therapeutic individualization.

In the study of seven patients by Carboni et al., All received empirical antibiotics, six additionally received ritonavir/lopinavir, and only one received hydroxychloroquine. [21].

In a publication in The Lancet, $95 \%$ of patients received antibiotics and $21 \%$ received lopinavir/ritonavir.
Corticosteroid use differed significantly between survivors and non-survivors. [17]

Three-quarters of the patients presented bilateral interstitial infiltrates on chest X-rays, which was present in all the deceased.

In this regard, Carboni et al. Describe that chest radiography upon admission frequently revealed bilateral interstitial infiltrates. [21] Wang et al. Reported the same findings in symptomatic patients. [18]

COVID-19 has been reported as the cause of elevated transaminases in $15 \%$ to $53 \%$ of patients. Elevation of aminotransferases is more common, with occasional elevation of alkaline phosphatase and total bilirubin. Liver damage appears to be more common in patients with severe cases of COVID-19. [28-31] In this series, discharge status with transaminase values was highly statistically significant.

LDH was increased in a high percentage of cases, exceeding the average value in deceased cases, which coincides with that reported by Fei Zhou et al. [14] Other studies also reached this conclusion. [18, 32-34]

In the Carboni et al. Sample, the average lymphocyte value was 1222. [21] The baseline lymphocyte count was significantly higher in, in the case of Fei Zhou et al. [17] Similar to that reported in this study. Average lactate was generally conserved in survivors and deceased, which was repeated in the study by Carboni et al. [21] The average value of albumin was also conserved in this author's study. [21]

\section{Conclusions}

In this study, mortality from COVID-19 was associated with age, with an increase in ICU stay, with higher APACHE II scores, with a decrease in ESR and lymphocyte count, with some degree of malnutrition, with an increase of transaminases and LDH. The groups of drugs used influenced survival. These results were highly statistically significant. For its part, Arterial hypertension was the most recurrent pathological antecedent.

\section{Appendix}

Table 5. Physiological variables of the APACHE II score.

\begin{tabular}{|c|c|c|c|c|c|c|c|c|c|}
\hline \multicolumn{10}{|l|}{ APACHE II score } \\
\hline \multicolumn{10}{|c|}{ Acute physiological disturbance score (APS) } \\
\hline Points & +4 & +3 & +2 & +1 & $\mathbf{0}$ & +1 & +2 & +3 & +4 \\
\hline Temperature & $\geq 41$ & $39-40,9$ & & $38,5-38,9$ & $36-38,4$ & $34-35,9$ & $32-33,9$ & $30-31,9$ & $\leq 29,9$ \\
\hline MAP (mmHg) & $\geq 160$ & $130-159$ & $110-129$ & & $70-109$ & & $50-69$ & & $\leq 49,9$ \\
\hline HR (beats/ min) & $\geq 180$ & $140-179$ & $110-139$ & & $70-109$ & & $55-69$ & $40-54$ & $\leq 39,9$ \\
\hline $\mathrm{RR}$ (respiration/min) & $\geq 50$ & $35-49$ & & $25-34$ & $12-24$ & $10-11$ & $6-9$ & & $\leq 5$ \\
\hline Oxygenation & $\geq 500$ & $350-499$ & 200-349 & & $200-70$ & $61-70$ & & $55-60$ & $<55$ \\
\hline Arterial $\mathrm{pH}$ & 7,7 & $7,6-7,69$ & & $7,5-7,59$ & $7,33-7,49$ & & $7,25-7,32$ & $7,15-7,24$ & $<7,15$ \\
\hline $\mathrm{HCO}^{-}(\mathrm{meq} / \mathrm{L})$ & 52 & $41-51,9$ & & $32-40,9$ & $23-31,9$ & & $18-21,9$ & $15-17,9$ & 15 \\
\hline $\mathrm{Na}^{+}(\mathrm{meq} / \mathrm{L})$ & $\geq 180$ & & $160-179$ & $155-159$ & $150-154$ & $130-149$ & $120-129$ & $11-119$ & $\leq 110$ \\
\hline $\mathrm{K}^{+}(\mathrm{meq} / \mathrm{L})$ & $\geq 7$ & $6-6,9$ & & $5,5-5,9$ & $3,5-5,4$ & $3-3,4$ & 2.9 & 2,5 & $<2,5$ \\
\hline Serum creatinine $(\mathrm{mg} / \mathrm{dL})$ & $\geq 3,5$ & $2-3,4$ & $1,5-1,9$ & & $0,6-1,4$ & & 0,6 & & \\
\hline Hematorit (\%) & $\geq 60$ & $50-59,9$ & & $46-49,9$ & $30-45,9$ & & $20-29,9$ & & $<20$ \\
\hline Leukogram & $\geq 40$ & $20-39,9$ & & $15-19,9$ & $3-14,9$ & & $1-2,9$ & & $<1$ \\
\hline
\end{tabular}

Glasgow coma scale: Score inversely proportional to the decrease in the state of consciousness to lead to 3 points of Glasgow coma scale equivalent to 12 points of APACHE II score. 


\begin{tabular}{ll}
\hline & Points \\
\hline Age adjustment & \\
$<44$ & 0 \\
$45-54$ & 2 \\
$55-64$ & 3 \\
$65-74$ & 5 \\
$\geq 75$ & 6 \\
Chronic process adjustments & 1 \\
Biopsy-proven cirrhosis & 2 \\
$\quad$ Heart failure Class IV of the NYHA & 3 \\
Severe COPD & 4 \\
Chronic dialysis & 5 \\
Immunosuppression & 2 \\
Elective surgery & 2 \\
Urgent surgery & \\
\hline
\end{tabular}

Source Adapted from Knaus WA, Drapper EA, Wagner DP, Zimmerman JE. APACHE II: a severity of disease classification system. Crit Care Med. 1985; 13: $818-29$.

Abbreviations: MAP: Mean arterial pressure; HR: Heart rate; RR: respiratory rate.

Table 6. Nutritional Control (CONUT, acronym in Spanish).

\begin{tabular}{lllll}
\hline Indicators of degree of malnutrition & Normal & Mild & Moderate & Severe \\
\hline Albumin $(\mathrm{g} / \mathrm{L})$ & $\geq 35$ & $30,0-34,9$ & $25,0-29,9$ & $<25,0$ \\
Scoring & 0 & 1 & 2 & 3 \\
Cholesterol $(\mathrm{mmol} / \mathrm{L})$ & $\geq 4,6$ & $3,6-4,5$ & $2,5-3,5$ & $<2,5$ \\
Scoring & 0 & 1 & 2 & 3 \\
Total lymphocyte count $\left(\mathrm{mm}^{3}\right)$ & $>1600$ & $1200-1599$ & $800-1200$ & $<800$ \\
Scoring & 0 & 1 & 2 & 3 \\
Total scoring & $0-1$ & $2-4$ & $5-8$ & $>8$ \\
\hline
\end{tabular}

Source: Adapted from Hernández OM, Hernández JA, Núrquez MA, Padrón MA. El estado nutricional al ingreso en una unidad de cuidados críticos como factor pronóstico de la evolución de la sepsis. Rev Cubana Aliment Nutr. 2018 [Nutritional status on admission to a critical care unit as a prognostic factor for the evolution of sepsis. Cuban magazine of food and nutrition. 2018] [Internet] [Access: 14/07/2020]; 28 (2): 314-27. Available in: http://www.revalnutricion.sld.cu/index.php/rcan/article/view/604

\section{References}

[1] Guan WJ, Ni ZY, Hu Y, Liang WH, Ou CQ, He JX, et al. China Medical Treatment Expert Group for C, (2020). Clinical Characteristics of Coronavirus Disease 2019 in China. N Engl J Med [Online magazine]. 2019 [Access: 14/07/2020]; 382: 1708-20. Available https://www.nejm.org/doi/full/10.1056/NEJMoa2002032.

[2] Gobierno de España. Actualización 46 COVID-19. Ministerio de Sanidad, Consumo y Bienestar Social; 2020. [Government of Spain. Update 46 COVID-19. Ministry of Health, Consumption and Social Welfare; 2020] [Internet] [Access: 14/07/2020]. Available in: https://www.mscbs.gob.es/profesionales/saludPublica/ccayes/a lertasActual/nCovChina/do cumentos/Actualizacion_46_COVID-19.pdf.

[3] OMS. Alocución de apertura del Director General de la OMS en la rueda de prensa sobre la COVID-19 celebrada el 11 de marzo de 2020. OMS; 2020 [WHO. Opening speech of the director general of the WHO at the press conference on COVID-19 held on March 11, 2020. WHO; 2020] [Internet] [Access: 14/07/2020]. Available in: https://www.who.int/es/dg/speeches/detail/who-directorgeneral-s-opening-remarks-at-the-media-briefing-on-COVID19 11-march-2020.

[4] MINSAP. Protocolo de actuación nacional para la COVID-19. MINSAP; 2020 [Ministry of Public Health. National care protocol for COVID-19. Ministry of Public Health] [Internet] [Access: 14/07/2020]. Available in: https://files.sld.cu/editorhome/files/2020/05/MINSAP Protoc olo-de-Actuaci\%25C3\%25B3n-Nacional-para-la-COVID-19_ versi $\% 25 \mathrm{C} 3 \% 25 \mathrm{~B} 3$.

[5] MINSAP. Parte de cierre del día 13 de julio a las 12 de la noche. Sitio Oficial del gobierno del MINSAP de Cuba; 2020 [Ministry of Public Health. Closing part of July 13 at 12 at night. Official site of the Government of the Ministry of Public Health of Cuba] [Internet] [Access: 14/07/2020]. Available in: https://salud.msp.gob.cu/parte-de-cierre-del-dia-13-de-julio-alas-12-de-la-noche/.

[6] Chih Cheng L, Tzu Ping S, Wen Chien K, Hung Jen T, Po Ren $\mathrm{H}$. Severe acute respiratory syndrome coronavirus 2 (SARS-CoV-2) and corona virus disease-2019 (COVID-19): the epidemic and the challenges. International Journal of Antimicrobial Agents [Internet]. 2020 [Access: 06/04/2020]; 55:[aprox. $\quad 1 \quad$ p.]. Available in: http://doi.org/10.1016/j.ijantimicag.2020.105924.

[7] Chisakuta AM, Alexander JP. Audit in intensive care. The APACHE II classification of severity of disease. Ulster Med J [Internet] 1990 [Access: 29/05/2020]; 59: 161-7. Available in: https://www.ncbi.nlm.nih.gov/m/pubmed/2278113.

[8] Knaus WA, Drapper EA, Wagner DP, Zimmerman JE. APACHE II: a severity of disease classification system. Crit Care Med. 1985 [Access: 29/05/2020]; 3: 818-29. Available in: https://www.ncbi.nlm.nih.gov/m/pubmed/3928249. 
[9] Salluh JI, Soares M. ICU severity of illness scores: APACHE, SAPS and MPM. Curr Opin Crit Care. 2014 [Access: 29/05/2020]; 20 (5): 557-65. Available in: https://www.ncbi.nlm.nih.gov/m/pubmed/25137401.

[10] De Ulibarri Pérez JI, González-Madrño Giménez A, González Pérez P, Fernández G, Rodríguez Salvanéz F, Mancha Álvarez-Estrada A, et al. Nuevo procedimiento para la detección precoz y control de la desnutrición hospitalaria. Nutrición Hospitalaria (España). 2002 [New procedure for the early detection and control of hospital nutrition. Hospital Nutrition (Spain). 2002] [Internet] [Access: 14/07/2020]; 17: 179-88. Available http://www.nutricionhospitalaria.com/pdf/3323.pdf.

[11] Hernández OM, Hernández JA, Núrquez MA, Padrón MA. El estado nutricional al ingreso en una unidad de cuidados críticos como factor pronóstico de la evolución de la sepsis. Rev Cubana Aliment Nutr. 2018 [Nutritional status on admission to a critical care unit as a prognostic factor for the evolution of sepsis. Cuban magazine of food and nutrition. 2018] [Internet] [Access: 14/07/2020]; 28 (2): 314-27. Available

http://www.revalnutricion.sld.cu/index.php/rcan/article/view/6 04.

[12] ARDS Defnition Task Force, Ranieri VM, Rubenfeld GD, Thompson BT, et al. Acute respiratory distress syndrome: the Berlin defnition. JAMA 2012 [Access: 14/07/2020]; 307: 2526-33. Available https://pubmed.ncbi.nlm.nih.gov/22797452/.

[13] CECMED. Centro de Inmunología Molecular. Itolizumab. (Anti CD6). Cuba abril del 2020 [Center for Molecular Immunology. Itolizumab (Anti CD6)] [Internet] [Access: 14/07/2020].

Available

https://www.cecmed.cu/registro/rcp/heberonr-

alfa-r-3-m-interferon-alfa-2b-humano-recombinante.

[14] CECMED. Centro de Ingeniería Genética y Biotecnología. Heberferon Alfa R $10 \mathrm{M}$. (Interferon alfa 2B humano recombinante). Cuba 2020 [Center for Genetic engineering and biotechnoogy. Heberferon Alfa R 10 M. (Recombinant human interferón alfa 2B). Cuba, 2020] [Internet] [Access: 14/07/2020] Available in: https://www.cecmed.cu/COVID-19/aprobaciones/itolizumab-a nti-cd6-0.

[15] CECMED. Centro de Ingeniería Genética y Biotecnología. Jusvinza (CIGB 258). Cuba. Junio del 2020 [Center for Genetic engineering and biotechnoogy. Jusvinza (CIGB 258)] [Internet] [Access: 14/07/2020]. Available in: https://www.cecmed.cu/COVID-

19/aprobaciones/jusvinza-cigb-258-1.

[16] Hospital General de Massachusetts. Estratificación de riesgo COVID. [Access: 14/07/2020]. Available in: https://www.massgeneral.org/asset/MGH/pdf/news/coronaviru s/estratificacion-de-riesgo- COVID.pdf.

[17] Zhou F, Yu T, Du R, Fan G, Liu Y, Liu Z, et al. Clinical course and risk factors for mortality of adult inpatients with COVID-19 in Wuhan, China: a retrospective cohort study. The Lancet [revista en Internet]. 2020 [Access: 14/07/2020]; 395 (10229): 1054-62. Available in: https://www.thelancetcom/lancet/article/s0140-6736(20)30566 -3 .

[18] Wang D, Hu B, Hu C, Zhu F, Liu X, Zhang J, et al. Clinical Characteristics of 138 Hospitalized Patients With 2019 Novel
Coronavirus-Infected Pneumonia in Wuhan, China. JAMA. 2020 [Access: 14/07/2020]. Available in: https://jamanetwork.com/journals/jama/fullarticle/2761044.

[19] $\mathrm{Wu} \mathrm{Z,} \mathrm{McGoogan} \mathrm{JM.} \mathrm{Characteristics} \mathrm{of} \mathrm{and} \mathrm{Important}$ Lessons from the Coronavirus Disease 2019 (COVID-19) Outbreak in China: Summary of a Report of 72314 Cases From the Chinese Center for Disease Control and Prevention. JAMA. 2020 [Internet] [Access: 14/07/2020]. Available in: https://jamanetwork.com/journals/jama/fullarticle/2762130.

[20] Goyal P, Choi JJ, Pinheiro LC, Schenck EJ, Chen R, Jabri A, et al. Clinical Characteristic of COVID-19 in New York City. $\mathrm{N}$ Engl J Med. 2020 [Internet] [Access: 14/07/2020]. Avaliable

https://www.nejm.org/doi/full/10.1056/NEJMc2010419.

[21] Carboni BI, Huespe I, Lockhart C, Massó A, González AJ, Hornos M, et al. COVID-19 en la terapia intensiva. análisis de la experiencia durante el primer mes de la pandemia. MEDICINA. 2020 [Internet] [Access: 14/07/2020]; 80 (4). Available https://www.medicinabuenosaires.com/indices-de-2020/volum en-80-año-2020-s-3-indice/COVID_terapia/.

[22] Pan L, Mu M, Yang P. Clinical characteristics of COVID-19 patients with digestive symptoms in Hubei, China: a descriptive, cross-sectional, multicenter study. Am J Gastroenterol. 2020 [Internet] [Access: 14/07/2020]. Available in: https://pubmed.ncbi.nlm.nih.gov/32287140/.

[23] American Academy of Otolaryngology-Head and Neck Surgery. AAO-HNS: anosmia, hyposmia, and dysgeusia symptoms of coronavirus disease. March 22, 2020. [Internet] [Access: 14/07/2020]. Available in: https://www.entnet.org/content/aao-hns-anosmiahyposmia-and-dysgeusia-symptoms-coronavirus-disease.

[24] Giacomelli A, Pezzati L, Conti F. Self-reported olfactory and taste disorders in SARS- CoV-2 patients: a cross sectional study. Clin Infect Dis. 2020 March 26. 2020 [Internet] [Access: 14/07/2020]. Available in: https://pubmed.ncbi.nlm.nih.gov/32215618/.

[25] Bhatraju PK, Ghassemieh BJ, Nichols M. COVID-19 in critically Ill patients in the Seattle region - Case series. N Engl J Med 2020 [Internet] [Access: 14/07/2020]. Available https://www.ncbi.nlm.nih.gov/pmc/articles/PMC7143164/.

[26] Ruan Q, Yang K, Wang W, Jiang L, Song J. Clinical predictors of mortality due to COVID-19 based on an analysis of data of 150 patients from Wuhan, China. Intensive Care Medicine. 2020 [Internet] [Access: 14/07/2020]. Available in: https://pubmed.ncbi.nlm.nih.gov/32125452/.

[27] Qingxian C, Fengjuan Ch, Fang L, Xiaohui L, Tao W, Qikai $\mathrm{W}$, et al. Obesity and COVID-19 Severity in a Designated Hospital in Shenzhen, China. [Internet] [Access: 03/07/2020]. Available in: http://dx.doi.org/10.2139/ssrn.3556658.

[28] Xu L, Lu M, Yang D, Zheng X. Liver injury during highly pathogenic human coronavirus infections. Liver International. 2020 [Internet] [Access: 14/07/2020]. Available in: https://pubmed.ncbi.nlm.nih.gov/32170806/.

[29] Fan Z, Chen L, Li Jun et al. Clinical Features of COVID-19-Related Liver Damage. medRxiv 2020. [Internet] [Access: 14/07/2020]. Available in: https://doi.org/10.1101/2020.02.26.20026971. 
[30] Chen N, Zhou M, Dong X. Epidemiological and clinical characteristics of 99 cases of 2019 novel coronavirus pneumonia in Wuhan, China: a descriptive study. Lancet. 2020 [Internet] [Access: 14/07/2020]; 395 (10223): 507-513. Available in: https://www.thelancet.com/journals/lancet/article/PIIS0140-67 36(20)30211-7/fulltext.

[31] Hospital General de Massachusetts. El hígado y el COVID-19 [Liver and COVI-19] [Internet] [Access: 14/07/2020]. Available

https://www.massgeneral.org/asset/MGH/pdf/news/coronaviru s/el-higado- y-COVID-19.pdf.

[32] Lippi G, Plebani M. Laboratory abnormalities in patients with COVID-2019 infection. Clin Chem Lab Med. 2020 [Internet]
[Access: 14/07/2020]. Available in: https://pubmed.ncbi.nlm.nih.gov/32119647/.

[33] Lippi G, Plebani M. Procalcitonin in patients with severe coronavirus disease 2019 (COVID-19): a meta-analysis. Clin Chim Acta. 2020 [Internet] [Access: 14/07/2020]; 505: 190-1. Available in: https:/www.ncbi.nlm.nih.gov/pmc/articles/PMC7094472/.

[34] Herold T, Jurinovic V, Arnreich C. Level of IL-6 predicts respiratory failure in hospitalized symptomatic COVID-19 patients. medRxiv April 2020 [Internet] 2019 [Access 14/07/2020]. Available in: https://www.medrxiv.org/content/10.1101/2020.04.01.200473 81 v2Acknowledgements. 